\title{
Upaya Peningkatan Kesadaran Masyarakat Tentang Bahaya Gigitan Nyamuk Pada Bayi, Balita dan Ibu Hamil
}

\author{
Ika Putri Damayanti, SST, M.Kes ${ }^{(1)}$, Dita Rahifah ${ }^{(2)}$ \\ (1),(2) STIKes Hang Tuah Pekanbaru \\ Email: $\underline{\text { ikaputridamayanti@gmail.com }}$
}

\begin{abstract}
ABSTRAK
Health is a basic need of every individual society that must be met by every nation and country. This includes the state's obligation to protect its people from contracting diseases deemed dangerous.

Based on the results of a survey by students of DIII Midwifery Stikes Hang Tuah Pekanbaru which was conducted at RT 003 RW 003 Desa / Kelurahan Maharani, Rumbai District, it was found that the majority of the population's houses contained mosquitoes and gnats which could cause various diseases such as malaria, Dengue Hemorrhagic Fever (DHF), chikungunya., yellow fever, lymphatic filariasis and japanese ancehephalitis (inflammation of the brain)

Environmental health outreach activity "efforts to increase public awareness about the dangers of mosquito bites" which was held on 27 November 2019 at 09.30 WIB in the residential area of RT 003 RW 003 Maharani Village, Rumbai District, Pekanbaru City, which was attended by local residents. After carrying out this service activity, it is hoped that it can increase public awareness about the dangers of mosquito bites and increase knowledge and skills in the community to be able to maintain environmental health from the dangers of mosquito bites.
\end{abstract}

Keywords: danger of mosquito bites, awareness raising

Keywords: Early Detection, Degenarative Diseases, Elderly

\begin{abstract}
ABSTRAK
Kesehatan merupakan kebutuhan dasar setiap individu masyarakat yang harus dipenuhi oleh setiap bangsa dan negara. Termasuk kewajiban negara untuk memproteksi masyarakatnya tertular penyakit yang dianggap berbahaya.

Berdasarkan hasil survey mahasiswa DIII Kebidanan Stikes Hang Tuah Pekanbaru yang dilakukan di RT 003 RW 003 Desa/Kelurahan Maharani, Kecamatan Rumbai didapatkan bahwa mayoritas rumah penduduk banyak terdapat Nyamuk dan agas yang dapat menyebabkan berbagai penyakit seperti malaria, Demam Berdarah Dengue (DBD), chikungunya, demam kuning, filariasis limfatik dan japanese ancehephalitis (radang otak)

Kegiatan sosialisasi kesehatan lingkungan "upaya peningkatan kesadaran masyarakat tentang bahaya gigitan nyamuk" yang telah diselenggarakan pada tanggal 27 November 2019 pukul 09.30 WIB di kawasan rumah warga RT 003 RW 003 Kelurahan Maharani Kecamatan Rumbai Kota Pekanbaru, yang dihadiri warga setempat. Setelah dilakukan kegiatan pengabdian ini diharapkan dapat meningkatkan Kesadaran Masyarakat tentang Bahaya Gigitan Nyamuk dan meningkatkan pengetahuan dan keterampilan pada masyarakat untuk dapat menjaga kesehatan lingkungan dari bahaya gigitan nyamuk.
\end{abstract}

Kata Kunci: bahaya gigitan nyamuk, peningkatan kesadaran 


\section{PENDAHULUAN}

Kesehatan merupakan kebutuhan dasar setiap individu masyarakat yang harus dipenuhi oleh setiap bangsa dan negara.Termasuk kewajiban negara untuk memproteksi masyarakatnya tertular penyakit yang dianggap berbahaya.Negara sebagai organisasi terbesar diharapkan mampu untuk memberikan pelayanan yang maksimal terhadap penanggulangan penyakit tertentu, karena negara mempunyai kewenangan yang meliputi keseluruhan kehidupan bermasyarakat. Seperti yang tercantum dalam pasal 9 ayat 1 dan 2 dalam Undang-Undang RI No 36 Tahun 2009 tentang kesehatan yaitu (1) setiap orang berkewajiban ikut mewujudkan, mempertahankan, dan meningkatkan derajat kesehatan masyarakat yang setinggi-tingginya, (2) kewajiban sebagaimana dimaksud pada ayat (1), pelaksanaannya meliputi upaya kesehatan perseorangan, upaya kesehatan masyarakat, dan pembangunan berwawasan kesehatan. Untuk itu sudah selayaknya negara memberikan jaminan kesehatan kepada masyarakatnya.Termasuk dalam penanggulangan penyakit berbahaya yang dimana negara dianggap perlu turun tangan untuk mengatasi permasalahan penyakit tersebut.Salah satu penyakit yang dianggap momok bagi bangsa Indonesia ialah Demam Berdarah Dengue (DBD).

Penyakit Demam Berdarah Dengue merupakan penyakit yang berbahaya dimana penderitanya akan mengalami demam dengue yang disertai pembesaran hati dan manifestasi perdarahan yang mana menyebabkan gangguan pada pembuluh darah kapiler dan pada sistem pembekuan darah, sehingga mengakibatkan perdarahanperdarahan. Pada keadaan yang parah bisa terjadi kegagalan sirkulasi darah dan pasien jatuh syok hipovolemik akibat kebocoran plasma.Hingga kini belum ada vaksin atau obat anti virus bagi penyakit ini.
Penularan Demam Berdarah Dengue (DBD) terjadi melalui gigitan nyamuk aedes aegepty atau aedes albopictus betina yang sebelumnya telah membawa virus dalam tubuhnya dari penderita demam berdarah lain. Nyamuk aedes aegepty berasal dari Brasil dan Ethiopia, sering menggigit manusia pada waktu pagi dan siang.Orang yang beresiko terkena demam berdarah adalah anak-anak berusia 15 tahun, dan masyarakat yang tinggal di daerah lembab serta pemukiman kumuh.Penyakit ini sering terjadi dan muncul pada musim penghujan.

Permasalahan Demam Berdarah Dengue (DBD) tidak hanya berdampak pada masalah klinis individu yang terkena Demam Berdarah Dengue (DBD), tetapi juga berdampak pada kondisi Sosial dan Ekonomi.

Berdasarkan hasil survey mahasiswa DIII Kebidanan Stikes Hang Tuah Pekanbaru yang dilakukan di RT 003 RW 003 Desa/Kelurahan Maharani, Kecamatan Rumbai didapatkan bahwa mayoritas rumah penduduk banyak terdapat Nyamuk dan agas yang dapat menyebabkan berbagai penyakit seperti malaria, Demam Berdarah Dengue (DBD), chikungunya, demam kuning, filariasis limfatik dan japanese ancehephalitis (radang otak).

\section{METODE KEGIATAN}

Dalam kegiatan pengabdian ini metode yang digunakan adalah penyuluhan kesehatan upaya meningkatkan kesadaran masyarakat tentang bahaya gigitan nyamuk. Materi yang diberikan dalam penyuluhan adalah tentang penanggulangan gigitan nyamuk. Pelaksanan yang diberikan oleh mahasiswa DIII Kebidanan Stikes Hang Tuah pekanbaru yaitu dengan memberikan informasi mengenai penanggulangan bahaya gigitan nyamuk, yaitu dengan cara sebagai berikut Menjaga kebersihan dan kerapian rumah dapat membantu mencegah kehadiran dan 
perkembangbiakan nyamuk.Bersihkan secara rutin tempat-tempat gelap dan tenang di rumah, termasuk kolong tempat tidur, belakang furnitur, gorden, dan gudang

\section{HASIL DAN PEMBAHASAN}

\section{Hasil Pelaksanaan}

Kegiatan penyuluhan kesehatan tentang upaya peningkatan kesadaran masyarakat tentang bahaya gigitan nyamuk dan penanggulangannyaini telah dilaksanakan pada 27 November 2019 pada masyarakat setempat.

$\begin{array}{rr}\text { Berdasarkan } & \begin{array}{r}\text { pengamatan } \\ \text { berlangsung, }\end{array}\end{array}$

kegiatan pegabdian pada masyarakat ini memberikan hasil sebagai berikut

1. Meningkatnya pengetahuan dan kesadaran masyarakat tentang kesehatan lingkungan agar masyarakat terhindar dari bahaya gigitan nyamuk

2. Masyarakat dapat mengaplikasikan cara penanggulangan yang telah dipaparkan sehingga dapat menghasilkan dampak positif yaitu lingkungan yang sehat dan terhindar dari bahaya gigitan nyamuk.

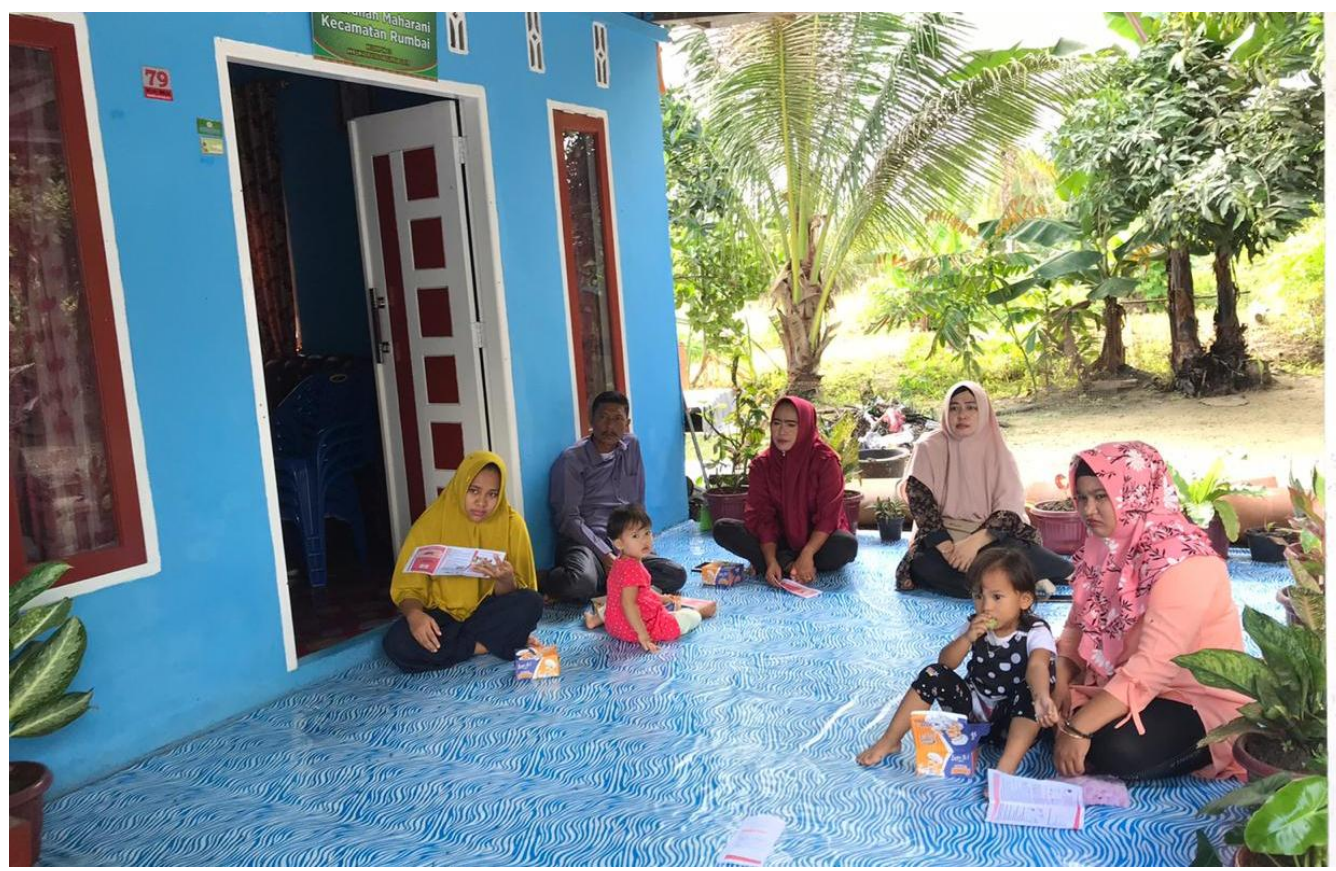

Keberhasilan penyuluhan dinilai dengan adanya peningkatan pengetahuan masyarakat akan bahaya gigitan nyamuk berdasarkan ketepatan dalam menjawab quiz dengan beberapa pilihan jawaban secara lisan setelah dilakukan penyuluhan dibanding sebelum dilakukan penyuluhan. Pertanyaan yang diajukan antara lain:

1. Bagaimana cara penanggulangan penyebaran nyamuk

2. Apa saja ciri-ciri nyamuk yang dapat menularkan DBD
Dari penilaian yang dilakukan, didapatkan peningkatan pengetahuan peserta dilihat ketepatan peserta dalam menjawab pertanyaan selingan setelah pemberian materi dibanding sebelum pemberian materi. Selain dari pertanyaan tersebut, penilaian keberhasilan penyuluhan juga dapat dilihat dari pertanyaan yang diajukan saat tanya jawab. Terdapat peserta yang bertanya dengan pertanyaan yang bervariasi dan diajukan secara serius saat sesi tanya jawab 
Keberhasilan penyuluhan dinilai dengan adanya peningkatan pengetahuan masyarakat akan bahaya gigitan nyamuk berdasarkan ketepatan dalam menjawab quiz dengan beberapa pilihan jawaban secara lisan setelah dilakukan penyuluhan dibanding sebelum dilakukan penyuluhan. Pertanyaan yang diajukan antara lain:

1. Bagaimana cara penanggulangan penyebaran nyamuk

2. Apa saja ciri-ciri nyamuk yang dapat menularkan DBD

Dari penilaian yang dilakukan, didapatkan peningkatan pengetahuan peserta dilihat ketepatan peserta dalam menjawab pertanyaan selingan setelah pemberian materi dibanding sebelum pemberian materi. Selain dari pertanyaan tersebut, penilaian keberhasilan penyuluhan juga dapat dilihat dari pertanyaan yang diajukan saat tanya jawab. Terdapat peserta yang bertanya dengan pertanyaan yang bervariasi dan diajukan secara serius saat sesi tanya jawab

\section{Pembahasan}

Keberhasilan penyuluhan dinilai dengan adanya peningkatan pengetahuan masyarakat akan bahaya gigitan nyamuk berdasarkan ketepatan dalam menjawab quiz dengan beberapa pilihan jawaban secara lisan setelah dilakukan penyuluhan dibanding sebelum dilakukan penyuluhan. Pertanyaan yang diajukan antara lain:

1. Bagaimana cara penanggulangan penyebaran nyamuk

2. Apa saja ciri-ciri nyamuk yang dapat menularkan DBD
Dari penilaian yang dilakukan, didapatkan peningkatan pengetahuan peserta dilihat ketepatan peserta dalam menjawab pertanyaan selingan setelah pemberian materi dibanding sebelum pemberian materi. Selain dari pertanyaan tersebut, penilaian keberhasilan penyuluhan juga dapat dilihat dari pertanyaan yang diajukan saat tanya jawab. Terdapat peserta yang bertanya dengan pertanyaan yang bervariasi dan diajukan secara serius saat sesi tanya jawab

\section{KESIMPULAN}

Dari kegiatan pengabdian masyarakat sampai saat ini dapat disimpulkan bahwa meningkatnya pengetahuan dan pemahaman masyarakat RT 003 RW 003 tentang masalah bahaya gigitan nyamuk dan solusinya, dimana pemeliharaan lingkungan selama ini yang kurang efektif yang dilakukan oleh masyarakat dapat berdampak penyebaran nyamuk sehingga dengan adanya penyuluhan ini diharapkan dapat memberikan dampak positif bagi masyarakat untuk dapat menjaga lingkungan sehingga terbebas dari nyamuk.

\section{DAFTAR PUSTAKA}

Depkes RI. 2004. Petunjuk Pelaksanaan

Pemberantasan Sarang Nyamuk DBD (PSN-DBD) oleh Juru Pemantau Jentik (Jumantik). Jakarta: Ditjen PPMPLP.

Depkes RI. 2007. Ayo Lakukan Gerakan Pemberantasan Sarang Nyamuk Demam Berdarah. Jakarta: Pusat Promosi Kesehatan 